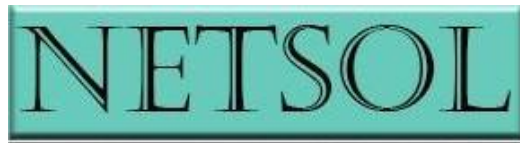

NEW TRENDS IN SOCIAL AND LIBERAL SCIENCES

An Interdisciplinary Journal

http://www.netsoljournal.net/

Volume 6, Issue 2, pp.1-13, Fall 2021

https://doi.org/10.24819/netsol2021.09

Date Submitted: February 11, 2021

Date Accepted: November 30, 2021

\title{
Ethno-Religious Conflict, Human Security and Peacebuilding in Contemporary Lagos
}

\author{
James Olusegun Adeyeri, Lagos State University, Ojo, Nigeria
}

\begin{abstract}
Lagos, the most populous city in Nigeria and economic hub of the country, is a mirror of complex ethnic and religious configuration of the Nigerian federation. This diverse ethnic and religious character, among other factors, makes Lagos a hotbed of violent ethnic conflicts. This condition is exacerbated by mutual fear and anxiety among various ethnic groups, particularly Yoruba, Hausa and Igbo, about domination, coupled with the pervasive feeling by some groups that other groups are the cause of their socio-economic and political misfortunes. In this setting, hopes and aspirations that antagonism and possible triumph may guarantee socio-economic benefits have often turned minor disagreements into violent conflicts, in which ordinary people are foot soldiers and greatest victims. The core problematic of this research is to investigate the fundamental causative factors and implications of ethnoreligious conflict in modern Lagos, Southwest Nigeria. Thus, this paper is a historical inquiry into the basis and impact of Yoruba-Hausa inter-ethnic violence on human security in contemporary Lagos society. The study also explores the opportunities for the attainment of sustainable peace and security within Nigeria. This study posits that the ethno-religious emotion and conviction that continuous antagonism and ultimate triumph against a particular ethnic group(s) assures socio-economic progress is false. The paper concludes that the best recipe for sustainable human well-being, peace and security for Nigerians is to collectively launch a sustained legitimate advocacy against corruption and abuse of public office rather than wasting precious human and material resources on divisive and counter-productive violent ethno-religious conflicts. The study adopts the historical method of data collection and analysis.
\end{abstract}

Key Words: Ethnicity, Religion, Poverty, Conflict, Human Security, Peacebuilding, Nigeria

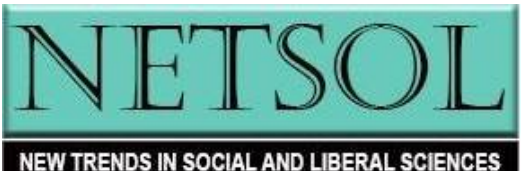




\section{Introduction and Historical Context}

Lagos, capital of Lagos state and former capital of Nigeria with over 21 million residents, is a cosmopolitan city and microcosm of Nigeria as it is populated by over two hundred fifty ethnic groups of Nigeria, as well as by people from neighbouring countries, such as Togolese, Beninoise, Ghanaians, among others. The autochthonous population of Lagos is dominated by the Awori, a sub-group of the Yoruba, one of Nigeria's three largest ethnic groups, while Igbo and Hausa-Fulani are the city's largest non-indigenous/Yoruba population, mostly from Eastern and Northern Nigeria respectively.

The origin of Hausa-Fulani settlements in Lagos started in the mid-nineteenth century. Mahdi Adamu asserts that one of the greatest sources of military support for Oba Buraimoh Adele, monarch of Lagos (r.1775-1780), and later, Oba Kosoko (r.1845-1851), were Hausa Muslim slaves (Adamu 1978; Akinola 2018: 6). Trade and commerce, particularly cow trade, have also been an important factor for Hausa-Fulani migration to Lagos. Indeed, there is a long history of long-distance trade between North and Southern Nigeria. As part of this historical and evolving trend, Hausa-Fulani people brought cows from the north to Lagos for sale, after which they bought items, such as rice, kola nuts, sugar, and flour, for sale on their return to the north. Some migrant workers also used to travel to Lagos for periodic residencies that spanned months working as barbers, rope makers, tending cattle, and other menial jobs, as well as performing minor surgical operations, such as cupping and bone-setting. Over time, the migrant traders settled in Lagos, often after getting married to Hausa women born in the city. It is worth noting that many Hausa-Fulani men and women were born and resided in Lagos (Ujorha 2012, 2016).

Colonial rule and its appurtenances, such as taxation, construction of roads and railways, promoted migration of Hausa-Fulani population to Lagos. In particular, the introduction of colonial taxation and the British administration's insistence on its payment with newly introduced British coins acted as a major push for the development of migrant labour wage. In addition, migration rapidly increased in response to new level of taxation and demand for labour in the towns and commercial crop zones. Some of the Hausa settlers constituted the core of the structure that later transformed into the Nigerian Police Force (Tijani 2003; Swindell 1984: 4; Obaro 2014: 42; Jubrilla n.d). The first major Hausa settlement in Lagos emerged in Obalende, Lagos Island. Following the conscription of these settlers into the Hausa Royal Constabulary and the West African Frontier Force (WAFF) which were deployed by the colonial government in its military campaigns and onslaught against slave traders within the Western District of Lagos, further settlements were created in Okokomaiko, Ado Soba, Ilemba Hausa, and Kemberi. Additional Hausa settlements later emerged in towns like Gogere, Aiyetoro, Mebamu, Alaba, Abule Aka, Ajangbadi, and Sabo-Oniba, etc. Today, Hausa-Fulani communities remain in Olodi Apapa, Idi Araba, Ketu/Mile 12, and Ikorodu (Kazeem 2000: 71; Lagos State Ministry of Information and Strategy 1998: 71; Ujorha 2012).

Contemporary Lagos, the study area of this paper, refers to the entire territory of current Lagos State, bordered in the North and East by Ogun State, and in the East by the Republic of Benin. The state comprises five administrative divisions (Badagry, Ikeja, Ikorodu, Lagos, and Epe), covering 20 Local Government Areas and 37 Local Council Development Areas (Lagos State Government 2017).

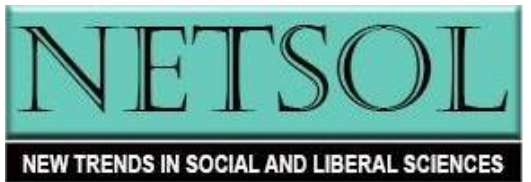


Except for Olubomehin (2011) and Animasawun (2016), existing literature on the subject as it relates to Nigeria have largely focused on ethno-religious conflicts in Northern Nigeria (e.g Kaduna, Jos, Tiv, and Jukun areas) ostensibly due to its prevalence in that part of the country. Lagos has had its share of the phenomenon and its negative consequences. Thus, Lagos is the geographical focus of this study. Main issues of this research include the impact of Yoruba-Hausa ethno-religious conflicts on human security, and opportunities and strategies for post-conflict peace-building within the study area.

\section{Clarification of Concepts}

The concept of ethno-religious conflict is important to the study of conflict in Lagos in view of the heterogeneous ethnic composition and religious mix of the study area. Ethnoreligious conflicts as defined by Kadayifci-Orellana are those conflicts in which groups are pitched against themselves in a society where religion constitutes an integral part of sociocultural life, and religious institutions are representative, possess moral legitimacy, and mobilisation potential. In this setting, parties to the conflict are defined by religious affiliations, and religious institutions represent a significant portion of the community's population, have moral legitimacy and the capacity for reaching out and mobilising adherents within the community, as has been the case in Lagos. By this conceptualisation, defining and distinguishing features of ethno-religious conflicts are centrality of identity issues, civilian causalities, intractability, centrality of religion and religious institutions, use of religious language, texts and images, impact of colonization, and crisis of legitimacy (KadayifciOrallana 2009: 265-267). Adetoye and Omilusi affirm that the nature of ethno-religious conflicts is such that the conflict can be both inter-group and intra-group in scope and character. In addition, ethno-religious conflicts are characterised by incompatibility, friction, opposition, antagonism, hostility, dispute, quarrel, and war as a result of differing and conflicting views defined along ethnic and religious identity lines (Adetoye and Omilusi 2015: 53; Ayantayo 2005). Aleyomi on his part avers that ethnic conflict and religious conflict are synonymous, arguing that a conflict that started originally as an ethnic one may transform into a religious conflict, and vice versa (Aleyomi 2012: 131). Madu and Ibrahim also hold a similar view, that religious conflicts and ethnic conflicts are usually hard to differentiate. He further opines that because ethno-religious conflicts by nature have the propensity to spread from their original theatre to other zones, such as neighbouring communities, states or even regions of the country, they are the most violent expressions of inter-group conflict in Nigeria (Madu and Ibrahim 2013: 151). From these definitions, it becomes clear that ethnic and religious identities, differences, perceptions, disagreements, and violent confrontations over contentious and conflicting interests are hallmarks of ethno-religious conflicts. It is also a type of conflict in which political and religious leaders take advantage of the community's ethno-religious cleavages to create crisis with a view to achieving certain narrow objectives. It needs to be added that, usually in states where nationhood is still rudimentary and weak, religious undercurrents contribute to conflicts involving persons/groups from different ethno-religious backgrounds even when the issues in contention were originally non-religious in nature. It is in this context that the conflicts under consideration in this paper fit into the ethno-religious conflict model, in view of the age-old Christian South-Muslim North perception and dichotomy.

The concept of human security is key to this study on account of the negative effects of globalisation, ethnic antagonisms, worsening poverty and criminality in contemporary Lagos.

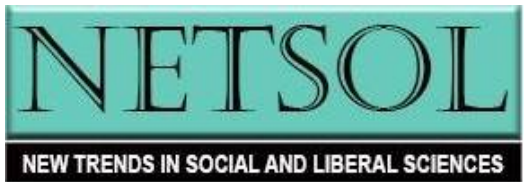


Human security, a relatively new concept, whose origin is traceable to the collapse of the Cold War, emerged because of the conviction that the realist, state-centric paradigm of international security that championed the primacy of territorial integrity over that of the individual, seemed increasingly anachronistic in a world where states no longer faced the existential threat that nuclear stand-off had perpetuated. In the post-Cold War period, wars between states had paled drastically, replaced by virulent globalisation and intransigent nationalisms inspired civil and ethnic wars, particularly in Africa, Asia and Eastern Europe, characterised by destruction of infrastructure, deliberate attacks on non-combatants, worsening and increasing proliferation of poverty, and promotion of criminal activities and illegal economies (Johns 2014). Therefore, in place of the old concept of security, the individual should be the reference of security. Under this new approach, international security is to be achieved through a merger of development and security, that is, making the emancipation and development of individual the fulcrum of security agenda, although the state, in conjunction with development agencies like NonGovernmental Organisations (NGOs) and other Civil Society groups, would still be the foremost guarantor of this security (Johns 2014; Kaldor 2007: 6; United Nations 2004).

The first authoritative and most cited definition of human security is that provided by the United Nations Development Program (UNDP) in 1994: “...first, safety from such chronic threats as hunger, disease, and repression. And second, it means protection from sudden and hurtful disruptions in the patterns of daily life-whether in homes, in jobs or in communities" (UNDP, 1994). In this context, human security also encompass freedom from fear and want. The UNDP categorised human welfare threats into seven non-exhaustive and non-exclusive security categories, namely, economic, political, community, environmental, food, health, and personal. According to the agency, the core characteristics of human security are that it is universal, people-centred, its components are interdependent, and it is best ensured through prevention. Despite intellectual criticisms of the UNDP definition partly on grounds of being too broad, it served as a core platform from which academic and other re-conceptualisations of human security emerged (Gregoratti 2013).

In Bajpai's view, "human security relates to the protection of the individual's personal safety and freedom from direct and indirect threats of violence... The promotion of human development and good governance, and, when necessary, the collective use of sanctions and force are central to managing human security... States, international organisations, nongovernmental organisations, and other groups in civil society in combination are vital to the prospects of human security" (Bajpai 2000: 1-4).

Annan, adopting perhaps the broadest approach so far, opines that human security encompasses far more than the absence of violent conflict, but also include human rights, good governance, access to education and health care, as well as opportunities and choices to actualize individual potentials. These steps will facilitate poverty reduction and economic growth, and thus aid conflict prevention. In all, he argues that freedom from want and fear, and the freedom of coming generations to inherit a healthy natural environment are connectedly the cornerstones of human security, and by extension, national security (Annan 2000). Thakur, following a similar path, views human security as the quality of life of the people, and that anything which undermines their quality of life, such as demographic pressures and diminished access to resources etc, is a security threat, while anything which can promote their quality of life, such as economic growth, increased access to resources, and socio-political empowerment is an enhancement of human security (Thakur 1997: 53-54). Similarly, Hammerstad defines human security as the attainment of the social, political, environmental, and economic

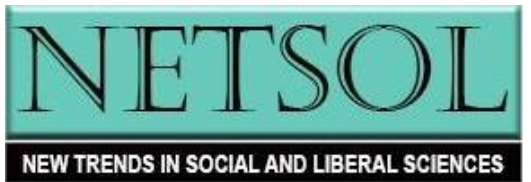


conditions under which individuals can live in freedom and dignity (Hammerstad 2000). These conceptualizations concur on the crucial importance of individual well-being, prosperity, safety, dignity, fundamental freedoms, and overall self-actualization as crucial elements of human security.

The concept of peacebuilding gained currency after 1992 following the UN SecretaryGeneral, Boutros-Boutros Ghali's pronouncement of his Peace Agenda. At one level, peacebuilding connotes activities that transcend crisis intervention, for example, long-term development, establishment of structures and institutions of governance, institutional reforms. It also involves capacity building of non-governmental organizations, such as religious institutions, for peace making and peacebuilding (Morris 2013: 1). Galtung views it as the process of establishing self-supporting structures that eliminate causes of war and provide alternatives to war in situations of probable occurrence of war. In this wise, mechanisms for resolving conflicts should be in-built in such structures as a permanent reservoir from which the system can tap whenever the need arises, rather than relying upon ad hoc measures (Galtung 1975: 282). The UN's conception of peacebuilding is an extension of Galtung's conceptualization in that the former defines it as activities carried out on the far side of conflict to re-establish the rubrics of peace and provide the tools for building on that foundation something more than mere absence of war. In effect, the nature and essence of peacebuilding is more profound and enduring than those of its predecessors, peacekeeping and peace making (Brahimi 2000: 3). For Lederach, peacebuilding is a broad concept that covers the creation and sustenance of the entire processes, approaches and stages required for conflict transformation to more sustainable peaceful co-existence. Peacebuilding thus encompasses various activities that are undertaken prior to and after official peace agreements, such as building legal and human rights institutions, just and effective governance, and dispute resolution processes and frameworks. For effective peacebuilding, careful and participatory planning, coordination of various activities and efforts, and sustained commitments by local and international partners are vital. (Lederach 1997: 20, 82-83; Morris 2013: 1). In sum, effective peacebuilding is of crucial importance for sustainable peace and prevention against relapse into conflict in a postconflict society.

\section{Yoruba-Hausa Conflict and Human Security in Contemporary Lagos}

Violent conflicts between Yoruba and Hausa communities/groups in Lagos during the post-independence period date back to about 1999. Usually, such conflicts began as minor disagreements between few individuals from the ethnic divide, before swiftly escalating into violent confrontations as a result of varied forms of solidarity interventions. The Ketu riot, as the conflict of 1999 came to be known, erupted in late November over a contest between Hausa and Yoruba traders for control of the very important and popular Mile 12 Market in Ketu, Kosofe Local Government Area of Lagos State. It is to be noted that although Ketu was originally a predominantly Yoruba town, waves of Hausa migrations to the area over the decades soon led to the emergence of a large Hausa community in the Ketu-Mile 12 axis. One major implication of this development was that by 1999 the Hausa community had become a major player and thus was in a position to compete with their Yoruba hosts for power and influence in the day-to-day affairs of the market. The dispute and struggle for supremacy soon escalated into a bloody fighting following the entry of Yoruba nationalists' Oodua People's Congress (OPC) fighters into the market to demand the appointment of a Yoruba as leader of the Shukuru Yam Sellers Market Association, on account of the location of the market on

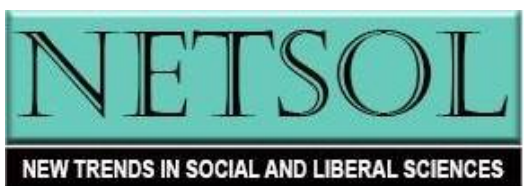


Yoruba soil (Ezeobi 2016; Immigration and Refugee Board of Canada 2000: 1). The OPC demand can be better understood in its wider context. The pan-Yoruba nationalist organization was established in August 1994 in the wake of General Ibrahim Babangida's (a Hausa-Fulani) annulment of the June 12, 1993 Presidential elections, widely acclaimed as the most credible in the country's political history, won by Chief M. K. O. Abiola, a Yoruba business mogul and philanthropist. OPC's immediate goal was to pressure the Babangida-led Federal Military Government to revalidate Abiola's June 12 mandate, but its wider objectives included the right to maximum self-determination by the Yoruba people, and to monitor and struggle for the protection of Yoruba interests, to mention a few (Oodua People's Congress 2018). Thus, OPC's demand for a Yoruba head for the Mile 12 market association was premised upon the organization's perception of itself as defender of Yoruba people, its territory, and interests.

However, OPC intervention in the Ketu conflict, widespread availability of small arms and other dangerous weapons and willing youths/fighters on both sides, and the attendant escalation bore serious consequences for human security in the Ketu-Mile 12 area, entire southwestern states and beyond. At the peak of the violent clashes in the second part of 2000, number of deaths had reached hundreds. There was a complete breakdown of law and order, bloody clashes occurred every week, and the security forces appeared to have lost control or were unwilling to intervene effectively until many lives had been lost. Consequently, many Hausa men and women ran away from the southwest to the north, some refusing to return ever since. General insecurity, and government's eventual closure of the market for many weeks, caused major loses to traders, whose products were either destroyed or rotten without adequate preservation (Human Rights Watch 2018). In addition, of significance was the establishment of the Arewa Peoples Congress (APC) as a fallout of the conflict. Although the Federal Government of Nigeria gave the police a shoot-on-sight order against OPC members resisting arrest in order to stem the rising death toll, a number of northern elders who were doubtful of government's capacity to secure the lives and property of northerners initiated moves that culminated in the creation of the APC in Ibadan on 27 December 1999 to act as a counterpoise to the OPC (Ezeobi 2016; West Africa 1999). Significantly, these opposing ethnic nationalist movements afterwards became the vanguards for canalizing and advancing, sometimes forcefully, the perceived interest of their respective ethnic groups in various parts of the multiethnic country at the expense of human security, nation-building and national development.

Another serious violent conflict between the Yoruba and Hausa occurred in October 2000 following the killing of a man, purported to be a receiver of stolen goods, by an alleged OPC vigilante patrol team in the Boundary community in Ajegunle. The Hausa community, angered by this action, launched an attack against the OPC anti-crime team, which resulted in the death of several OPC operatives. The violence subsequently escalated and spread spontaneously to neighbouring locations and communities, such as Malu Road, Tolu, Trinity, and Marine Beach, Ojo-Alaba Market, Ijora-Badia, Alaba-Suru Market (Orile), and Apapa Wharf. Like in the Ketu/Mile 12 conflict, prompt and effective intervention by the police was lacking. The bloody fighting which began on 15 October raged until 19 October when soldiers, allegedly paid by local residents and community leaders, eventually brought the situation under control (Human Rights Watch 2018; Aluko 2000). The involvement of the OPC, an ethnic militia, in crime fighting and security duties needs some clarification. It is argued in some quarters that this incursion by the OPC since late 1999 was inspired by increased popularity acquired by some other ethnic militias, such as the Bakassi Boys in Southeastern Nigeria, which had earlier made significant impact on violent crime reduction in its areas of operation

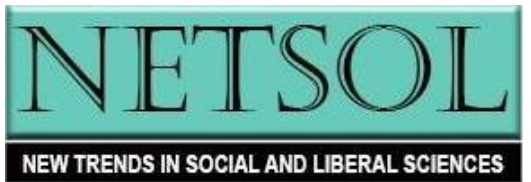


(Human Rights Watch 2018). It is incontrovertible that at that time, the OPC stepped in to fill the wide and scary human security lacuna in the Yoruba cities/states, especially Lagos.

There is need to note, however, that the Ajegunle conflict, in which the OPC was a major actor, resulted in serious undermining of human security due to the extensive destruction of lives, properties, and means of livelihoods. Over eighty people were killed in street fighting and targeted house attacks in the Ajegunle, Ojoo, Alaba, Okokomaiko, Orile and other areas. Dead bodies, some beheaded, others charred beyond recognition, littered the roads and streets, thereby underscoring the deep insecurity, and disregard for human life and humanity, within the society. Many people fled their homes to seek refuge elsewhere. In addition, dozens of cars, buses and houses and several other properties were burnt across the battle zones of the ferocious urban warfare that besieged the city for days (News24 Archives 2000; Aluko 2000).

Yoruba-Hausa Violence in Lagos erupted again on 2 February 2002, this time in Idi Araba, a crowded and impoverished suburb of the city, and later spread to the Mushin, Onipanu and Fadeyi neighbourhoods. Unlike the previous conflicts, the immediate cause of this conflict is unclear, given the plethora of accounts of what triggered the violent confrontations. Nonetheless, a common denominator in the accounts is the issue of urination or defecation in an inappropriate place. According to one of the most popular accounts, a Hausa man defecated in a place not designated as a public toilet, near an OPC meeting venue. Several Yoruba people, some of whom were probably OPC members, accosted him and demanded payment for his use of the space as a toilet. The man's refusal led to a fight between him and the small group of Yorubas. Following previous patterns, this quickly escalated into an armed conflict between large Hausa and Yoruba groups (Human Rights Watch 2018; Oyo 2002). The second major account claims that a young Christian ethnic Yoruba urinated or defecated near the compound of a Hausa man/mosque, an action that infuriated some Hausa Muslims who thus attacked him, possibly leading to his death. A revenge attack by some Yoruba men, later joined by OPC fighters, escalated and transformed the fighting into a Yoruba-Hausa ethnic armed conflict (Aluko 2002; Akoni 2002). A common denominator in these and other accounts is the issue of urination or defecation in an inappropriate place. A 'reckless' urination/defecation is unethical and unacceptable, but the fact that this a small incident triggers an ethnic conflict of a largescale and bloody magnitude is indeed worrisome. It stands to reason that the escalation occurred largely in the context of the historical and lingering ethno-religious North-South divide and mutual antagonism in an atmosphere of acute poverty and socio-economic deprivations (paucity of public toilets), in this case, between predominantly Muslim HausaFulani, and predominantly Christian and animist Yoruba.

The three-day streak of violence on 2-4 February 2002, like the previous conflicts earlier discussed, caused extensive damage to life, property, and human security, particularly as the bloodletting came barely a week after bomb explosions at the Ikeja Military Cantonment that killed at least thousand people. By the time the military was called in to restore order, the Idi-Araba violence had caused the death of at least 55 persons and burning of not less than 19 houses. The Nigerian Red Cross confirmed this conservative figure of the death toll and affirmed that it was providing care for over one hundred fifty victims of gun, machetes, and other dangerous weapons attacks at nearby hospitals. Sporadic shootings on the streets and the general atmosphere of insecurity and fear also created serious population displacements. People in the hundreds, mainly children, women, and the elderly, became internally displaced persons (IDPs) in the nearby Abalti Barracks, and hundreds took refuge at the Ikeja Police

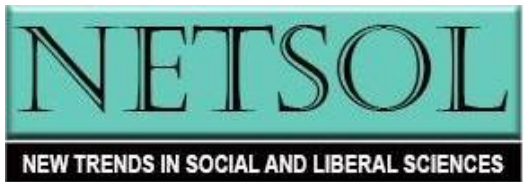


College refugee camp earlier created to shelter the large number of IDPs from the bomb explosions mentioned earlier (The New York Times 2002; Adepoju etal 2002).

Hausa-Yoruba relations underwent a thaw for about fourteeen years until violence broke out again on 2 March 2016 in the Ketu-Mile 12 area, reminiscent of the 1999-2000 bloody clashes between the two groups in the same neighbourhood. The conflict began as a verbal confrontation between vagrants (popularly called Area Boys), mostly Yoruba, and commercial motorcycle (Okada) operators, mainly Hausa, after a Hausa motorcyclist hit and killed a pregnant Yoruba woman. The 'minor' disagreement escalated into ethnic violence due to the former's refusal to take responsibility for the latter's medical treatment (Animasawun 2016; UNIC Press 2016). There is need to note that the Area Boy phenomenon has increasingly threatened human security in modern Lagos mainly due to mass unemployment and poverty alongside the negative effects of urbanization, such as homelessness. On the other hand, the huge and continuous increase of the Hausa motorcycle operators is linked to the mounting migration of Boko Haram IDPs to Lagos for refuge and 'greener pasture'. The retaliatory mobilisations and attacks by the opposing ethnic groups, caused the death of at least ten people, injury of one hundred and arson of twenty houses, forty vehicles and destruction of shops, motorcycles, sewing machines and other working tools. Over one hundred residents, particularly in the directly affected streets, such as Agilintin 1 and 2, Maidan, and Oniyanrin, fled their homes for safety (Usman etal 2016; UNIC Press; Nigeria Village Square 2016; Vanguard 2016; Animasawun 2016). Like in previous conflicts, underlying conditions of deep poverty and ethnic polarisation propelled the latest conflict and brought the involvement of outsiders, mostly Yoruba street urchins and Hausa motorbike operators this time.

The most recent Yoruba-Hausa violent confrontations in Lagos occurred on 15-16 March 2018 at Gida Panli, Kotomola, in Ojota. Violent clashes between Hausa and Yoruba youths began after a Hausa youth beat up, stabbed, and killed a Yoruba lad over a disagreement. The conflict escalated the next day following a reprisal attack by street urchins in the neighbourhood, during which a Hausa man was killed. Unlike in previous conflicts, the police response was quick and decisive. Policemen were deployed from different commands, as well as the Rapid Response Squad (RRS), which also provided air support. (Abdulfatai 2018; Oyenigbehin 2018). Although officers and men of the Nigeria Police contained the violence within 48 hours, several casualties still occurred. The actual number of persons killed remain unknown. Many motorcycles were destroyed, commerce in the area was grounded, and many scared parents took their schoolchildren home early (Abayomi 2018; Odunsi 2018).

\section{Post-Conflict Peacebuilding}

Government's response to the conflicts have been mostly haphazard and tentative in nature. Usually, in the wake of conflict between the two groups, police and other security personnel are deployed after violence escalated to restore peace, security, and order. This late deployment and slow interventions are among the major causes of the relatively high casualty figures. During and after a violence, government usually initiate meetings with the conflicting parties, traditional rulers, and other stakeholders, after which commitments and agreements on friendly and peaceful coexistence are reached amidst the state government's strong declarations of zero tolerance for violence. The Mile 12 Market conflicts have received the most government attention; the Bola Tinubu-led state government and Tunde Ibrahim-led Kosofe local government carried out a significant re-organisation of the market in response to the 1999 bloody conflict. They restructured the market into three core sections, namely, Shukura Yam

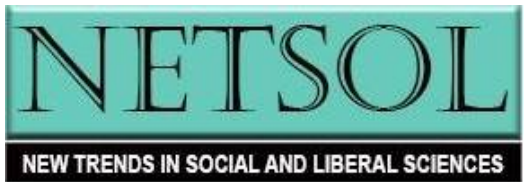


Sellers, Perishable Foodstuff, and Alaba Electronics. These sections were further broken down into many sub-units as a way of decentralising authority and control in the market to discourage conflict and promote peace. The state government also created the Inter-Ethnic Forum comprising Yoruba and Hausa leaders in the market, as well as some other members, to provide peace education to the market men and women and other inhabitants of ethno-religious conflict prone areas of the state. In addition, the government-brokered peace agreement introduced the elective principle whereby periodic elections are conducted in the market to elect market leaders and representatives (Lawal 2016). Unfortunately, government's timely and robust peacebuilding response to the 1999 conflict was not sustained.

As Lawal puts it, "Since the end of the violent attacks in the market in 1999, government has done practically nothing in building peace within the market. Apart from forcing an agreement on market leaders and setting up an Inter-Ethnic Forum which was short lived, most of the peacebuilding initiatives were put in place by the stakeholders (market and religious leaders) in the market" (Lawal 2018).

While an inclusive peacebuilding approach is important, government has a pivotal role to play in sustainable peace and human security. Moreover, government's peacebuilding initiatives should be comprehensive, sustained, and broad-based, covering all the conflictprone communities and the state, rather than concentrating on a single conflict zone for a short period after violent conflicts. It is worrisome that such an approach to post-conflict peacebuilding is not visible in any of the earlier discussed conflict zones of the state, where Hausa-Yoruba violence occurred in the past, such as Idi Araba and Ajegunle, or in other parts of the state. Durable peace and human security, peacekeeping, and peace enforcement, which have dominated government's response to the Lagos conflicts, should be complimented by broader peacebuilding approaches such as just, effective democratic governance, socioeconomic development, and societal conflict transformation.

\section{Conclusion}

From the preceding analysis, major precipitating factors for Hausa-Yoruba conflicts in contemporary Lagos are deep-seated ethnic and religious divisiveness and sentiments between the Muslim-dominated northern and predominantly Christian and animist southern parts of Nigeria. Although existing literature hardly refers to the conflicts as ethno-religious but prefer to describe them as ethnic, the conflicts are both ethnic and religious in motivation. As we noted earlier, it is very difficult to differentiate between ethnic conflict and religious conflict. While the ethnic character of the conflicts is openly manifest, the religious element epitomised by the age-old Muslim North-Christian South dichotomy is subsumed in the subconscious of the conflicting Hausa and Yoruba parties. But ethnic and religious differences ordinarily should not be automatic causes for a conflict, especially the recurrent type like that of Lagos. Beyond these cleavages, the socio-economic milieu of Hausa-Fulani relations in Lagos is a more fundamental explanation for recurrent conflict between the two groups. Put bluntly, abysmal poverty cum widespread socio-economic deprivations provides the enabling environment and impetus for primordial sentiments, such as ethnic and religious considerations to thrive as fault lines of conflict. It is the prevalent atmosphere of massive youth unemployment, acute poverty, hunger, anger, and despondency that has repeatedly fuelled escalation of minor disagreements into large-scale inter-ethnic armed violence. In addition, the lack of persistent schooling, which could contain conflict resolution skills, just does not exist for the impoverished population.

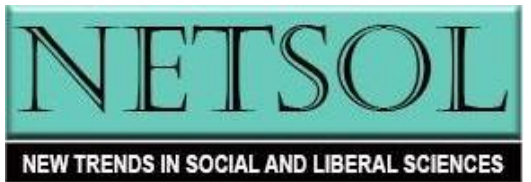


Many children do not past elementary school level, not to mention that electricity does not stay on reliably during the day or evening, although Nigeria is a net producer of oil.

Hausa-Yoruba conflict in Lagos has consistently threatened and undermined human security within the study area and even beyond. Many human lives have been lost, and the people, especially those in the conflict prone areas, live under fear and threat of resurgent or fresh violence. Extensive damage has been done to material property including homes, shops, and cars. Economic life and livelihood have been repeatedly disrupted, while many Nigerians have become refugees in their own country.

Government's response has been largely haphazard and tentative, usually concentrating on the peacekeeping and peace enforcement approaches, which have not been effective enough. An important theoretical implication of this study's findings is that further research is necessary to investigate why government's response to Yoruba-Hausa violent conflicts in Lagos overtime was not effective enough. The practical implications of the findings indicate that for sustainable peace and human security to be ensured, there is need for government to take up the central role in post-conflict peacebuilding, that should be proactive, comprehensive, and sustained. This should include effective and truly democratic governance that ensures civil liberty, freedom, and social justice to discourage people from taking matters in their hands and resorting to violence. It is crucial that the police force and judiciary consistently work as truly national and patriotic institutions by discharging their constitutional roles responsibly and fairly and ensuring that a fair sense of justice is distributed with rule of law. There is an urgent and increasing need to provide socio-economic empowerment to hordes of currently jobless, under-employed and angry Nigerian youths, who constitute a ready pool of foot soldiers for ethno-religious and other violent conflicts. But for widespread abject poverty and grossly inadequate social infrastructure, the Hausa man, who allegedly defecated in an inappropriate place and purportedly triggered the 2002 Idi Araba conflict, would have relieved himself in his home or in a public toilet. A permanent inter-faith dialogue and conflict resolution mechanism will help to provide early warning and response to potential conflict situations for conflict prevention, resolution, and overall peacebuilding. Finally, instead of wasting valuable human and material resources on divisive and counter-productive ethno-religious violent conflicts, Nigerians should collectively launch a consistent legitimate advocacy against poverty, official corruption, and abuse of public office, in order to achieve sustainable socio-economic development and human security.

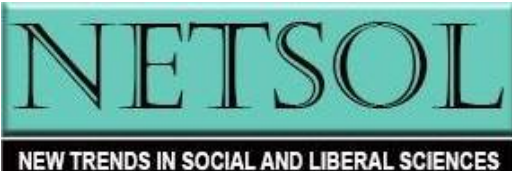




\section{References}

Abayomi J (2018) Panic as Yoruba, Hausa Clash in Lagos. Punch (Lagos), 16 March.

Abdulfatai A (2018) Two Feared Killed as Yoruba, Hausa Clash in Lagos. Punch (Lagos), 17 March.

Adamu M (1978) The Hausa Factor in West African History. Zaria \& Ibadan: Ahmadu Bello University Press \& Oxford University Press, Nigeria.

Adepoju F etal (2002) Nigeria: Idi-Araba Crises Spread, Soldiers Called in. P. M. News (Lagos), 4 February. Available at: www.allafrica.com/stories/2000. [Accessed 1 May 2018].

Adetoye D and Omilusi M (2015) Ethno-Religious Conflicts and Democracy in Nigeria. Global Journal of Arts, Humanities and Social Sciences 3 (1): 51-58.

Aleyomi M (2012) Ethno-Religious Crisis as a Threat to the Stability of Nigeria's Federalism. Journal of Sustainable Development in Africa 14 (3): 127-140.

Aluko M (2000) Igbo/Hausa/Yoruba 'Troubles in Lagos' in Lagos: The Military Called In. Available at: www.groups.google.com. [Accessed 18 April 2018].

Aluko M (2002) The Idi Araba 'Pissing'" Contest- and Nigeria's Tinder-Box. Available at: www.ngex.com. [Accessed 22 April 2018].

Animasawun G (2016) Inter-Ethnic Tensions in an Urban Setting: Recurring Clashes between Yoruba and Hausa in Mile 12 Market, Lagos, Nigeria. Available at: www.kujengaamani.ssrc.org/2016. [Accessed 13 May 2018].

Akoni O (2002) Nigeria: Death Toll Rises to 20 in Lagos Clash. Vanguard (lagos), 4 February. Available at: www.allafrica.com/stories/2000. [Accessed 22 April 2018].

Annan K (2000) Secretary-General Salutes International Workshop on Human Security in Mongolia. Two-Day Session in Ulaanbaatar, 8-10 May. Available at: www.un.org/News/Press/docs/2000/. [Accessed 8 March 2018].

Ayantayo J (2005) Sociological Examination of Inter-Religious Conflict in Africa. In: Albert I (ed) Perspectives on Peace and Conflict in Africa. John Archers: Ibadan, pp 55-64.

Akinola T (2018) Yoruba-Hausa Relations in Ojo Local Government Area of Lagos State (1967-2015): A Study in Intergroup Relations, Conflict Resolution and Peace-building. Proposal for PhD Thesis, Department of History and International Studies, Lagos State University, Ojo, Nigeria.

Bajpai K (2000) The Idea of a Human Security Audit. Joan B. Kroc Institute Report, 19. Available at: www.nd.edu/-krocinst/ocpapers/op_19_1. [Accessed 26 February 2018].

Brahimi L (2000) Report of the Panel on United Nations Peace Operations, A/55/305, S/2000. United Nations: New York.

Ezeobi C (2016) A Deadly Ethnic Clash. ThisDay Newspapers. Available at: www.thisdaylive.com. [Accessed 24 March 2018].

Galtung J (1975) Three Approaches to Peace: Peacekeeping, Peacemaking and Peacebuilding. In: Galtung J (ed) Peace, War and Defense-Essays in Peace Research. Ejlers: Copenhagen, pp 282-304.

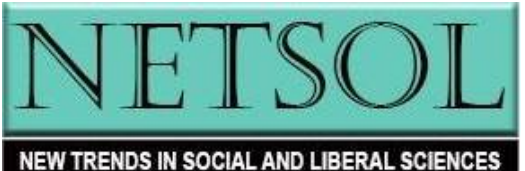


Gregoratti C (2013) Human Security. Britannica. com. Available at: www.britannica.com. [Accessed 22 February 2018].

Hammerstad A (2000) Whose Security? UNHCR, Refugee Protection and State Security after the Cold War. Security Dialogue 31(4): 395.

Human Rights Watch (2018) The Oodua People's Congress (OPC): Fighting Violence with Violence. Available at: www.hrw.org. [Accessed 24 March 2018].

Immigration and Refugee Board of Canada (2000) Nigeria: Causes and Consequences of Conflict and Violence between the Yoruba and Hausa in Lagos, Kosofe Local Government, Ketu Market area in December 1999. Available at: www.refworld.org/docid/... [Accessed 8 April 2018].

Johns L (2014) A Critical Evaluation of the Concept of Human Security. Available at: www.e-ir.info. [Accessed 22 February 2018].

Jubrilla A (n.d) Hausa Communities in Lagos from 1775. Unpublished PhD Thesis, University of Ilorin, Ilorin, Nigeria.

Kadayifci-Orellana S (2009) Ethno-Religious Conflicts: Exploring the role of Religion in Conflict Resolution. In: Bercovitch J, Kremenyuk, V and Zartman I (eds) The SAGE Handbook of Conflict Resolution. SAGE: London, pp 264-280.

Kaldor M (2007) Human Security. Polity Press: Cambridge.

Lagos State Government (2017) About Lagos. Available At: www.lagosstate.gov.ng. [Accessed 21 May 2018].

Lagos State Ministry of Information and Strategy (1998) An Authoritative Guidebook on Lagos State: Welcome to Lagos State. Royal Press Ltd: Lagos.

Lawal R (2016) An Assessment of Hausa/Yoruba Conflicts and Peacebuilding Initiatives in Mile 12 Market, Lagos, 1999-2014. Available at: www.researchgate.net/publicatio... [Accessed 16 May 2018].

Lawal R (2018) Return of Ethnic Tensions in Mile 12 Market. Available at: www.google.com/amp/thenationonlineng.net/return-ethnic-tensions-mile-12-market...[ Accessed 16 May 2018].

Lederach J (1997) Building Peace: Sustainable Reconciliation in Divided Societies. United States Institute of Peace Press: Washington, DC.

Madu A and Ibrahim G (2013) Ethno-Religious Conflict in Taraba State and Its Implications on SocioEconomic, Political and Educational Development of Youths. International Journal of Social Sciences and Humanities Review 4(3): 149-155.

Morris C (2013) What is Peacebuilding ? One Definition. Available at: www.peacemakers.ca. [Accessed 15 March 2018].

News24 Archives (2000) Lagos Clashes Leave 80 Dead. www.news24.com. Accessed 21 April 2018.

Nigeria Village Square (2016) Breaking News: Yoruba vs Hausa War in Mile 12 Lagos. Available at: www.nigeriavillagesquare.com/forum/threads/breakingnews... [Accessed 13 May 2018].

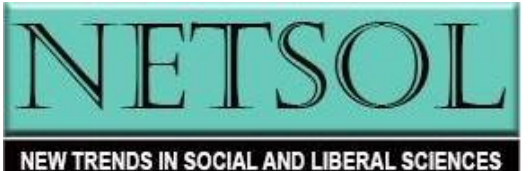


Obaro O (2014) The Nigeria Police Force and the Crisis of Legitimacy: Re-Defining the Structure and Function of the Nigeria Police. European Scientific Journal 10(8): 425.

Odunsi W (2018). Police, Ambode speak on Hausa, Yoruba Youths Bloody Clash. Daily Post (Nigeria). www.dailypost.ng>News. Accessed 14 May 2018.

Olubomehin O (2011) Communal and Ethnic Clashes in Nigeria: The Case of the Sagamu 1999 HausaYoruba Conflict. Journal of History and Diplomatic Studies 8.

Oyenigbehin J (2018) Commotion in Lagos as Hausa and Yoruba Clash Lead to the Death of Two People. Naija News, Available at: www.naijanews.com/2018/03/17/commotion-in-lagos... [Accessed 14 May 2018].

Oyo R (2002) Ethnic Militias Guard Tribal Divides. Word Press Review

Oodua People's Congress (2018) Available at: www.ooduapeoplescongress.org. [Accessed 24 March 2018].

Swindell K (1984) Farmers, Traders and Labourers: Dry Season Migration from the Northwest Nigeria 1900-1930. African Journal of the International Institute 54(1): 3-19.

Thakur R (1997) From National to Human Security. In: Harris S and Mack A (eds) Asia-Pacific Security: The Economics-Politics Nexus. Allen \& Unwin: Sydney, pp 52-80.

The New York Times (2002) $3^{\text {rd }}$ Day of Ethnic Violence in Streets of Lagos. Available at: www.mobile.nytimes.com/2002/02/05/world... [Accessed 1 May 2018].

Tijani A (2003) Sabo Communities in Yorubaland, Nigeria (1916-1967). Unpublished PhD Thesis, University of Ilorin, Ilorin, Nigeria.

Ujorha, T (2012) Olodi Apapa: A Charming Enclave of Hausas in Lagos. Daily Trust, 16 February.

Ujorha, T (2016) The Bambados of Lagos. Available at: www.dailytrust.com.ng. [Accessed 20 May 2018].

UNIC Press (2016) Survivors recount Yoruba, Hausa Deadly Brawl in Lagos. Available at: www.unicpress.com. [Accessed 13 May 2018].

United Nations (2004) A More Secure World: Our Shared Responsibility-Report of the High-level Panel on Threats, Challenges and Change. Available at: www.documents-dds-ny-un.org... [Accessed 21 May 2018].

UNDP (1994) Human Development Report 1994. [Accessed 3 November 2021]. Available at: http://hdr.undp.org/sites/default/files/reports/255/hdr 1994 en complete nostats.pdf

Usman E etal (2016) Lagos: Killings Continue in Mile 12 Ethnic Clash. Vanguard (Lagos) 5 March.

Vanguard (2016) Mile 12 Market Riots: Police arrest over 105 Suspects. Vanguard (Lagos) 4 March.

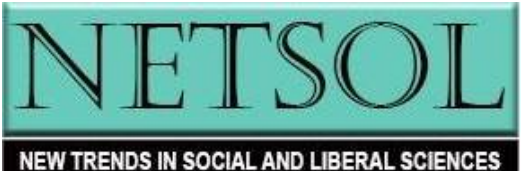

